\title{
Evaluasi Dampak Pengenaan Pajak Pertambahan Nilai pada Perdagangan Melalui Sistem Elektronik
}

Yanuar Wahyu Widianto ${ }^{1}$ dan Listia Sari Puspita ${ }^{2}$

Afiliasi

${ }^{1}$ Staf Badan Kebijakan Fiskal - Kementerian Keuangan Republik Indonesia.

${ }^{2}$ Staf di Lembaga Ilmu Pengetahuan Indonesia

Korespondensi: y.wahyuwidianto@gmail.com

\begin{abstract}
Abstrak
Defisit anggaran akibat pemberian stimulus dimasa Coronavirus disease COVID19 serta meningkatnya digitalisasi ekonomi, mendorong Pemerintah untuk menerbitkan Peraturan Menteri Keuangan (PMK) Nomor 48/PMK.03/2020 sebagai salah satu sumber penerimaan baru. Studi ini menganalisis peraturan tersebut menggunakan metode Regulatory Impact Assessment (RIA) guna mengetahui dampak bagi seluruh pemangku kepentingan dengan memberikan tiga alternatif kebijakan. Alternatif 1 do nothing diartikan bahwa Pemerintah tidak mengenakan PPN atas Perdagangan Melalui Sistem Elektronik (PMSE), alternatif 2 pengenaan PPN sesuai Peraturan Menteri Keuangan Nomor 48/PMK.03/2020, dan alternatif 3 pengenaan PPN dengan penambahan ketentuan baru. Berdasarkan hasil analisis biaya dan manfaat, alternatif 3: Pengenaan PPN dengan penambahan ketentuan baru merupakan pilihan terbaik karena memberikan manfaat yang paling besar dan biaya yang paling kecil. Penambahan ketentuan baru pada alternatif 3 yaitu dengan menambahkan lingkup pelaku usaha PMSE, dan menambahkan objek pajak PMSE.
\end{abstract}

Kata Kunci: Digitalisasi Ekonomi, Pajak Pertambahan Nilai (PPN), Regulatory Impact Assesment (RIA)

Doi: https://doi.org/10.47266/bwp.v3i2.76 | halaman: 109-125

Dikirim pada: 23 Juli 2020. Diterima pada: 27 Agustus 2020. Dipublikasikan pada: o7 September 2020 


\section{Pendahuluan}

\subsection{Latar Belakang}

Digitalisasi ekonomi mengalami peningkatan selama pandemi COVID-19 disaat pertumbuhan ekonomi global mengalami penurunan. Tercatat selama pandemi COVID19 pada bulan Januari 2020, penetrasi internet di Indonesia mencapai $64 \%$ dengan 175,4 juta pengguna internet, meningkat $17 \%$ antara tahun 2019 dan 2020 atau meningkat sebesar 25 juta pengguna (Data Reportal, 2020). Demikian pula dengan penetrasi media sosial di Indonesia yang mencapai 59\% dengan 160 juta pengguna media sosial pada bulan Januari 2020 (Data Reportal, 2020). Statista (2019) memproyeksikan pada tahun 2021 nilai transaksi e-commerce di Indonesia akan mencapai 4,9 triliun USD, sekitar 17,5\% dari nilai total penjualan melalui e-commerce secara global. Kondisi tersebut dapat menghasilkan peluang sekaligus tantangan pengenaan pajak dari ekonomi digital.

Di tingkat global, forum Inclusive Framework The Organisation for Economic Cooperation and Development (OECD) yang terdiri dari 129 negara tengah merumuskan konsensus internasional mengenai pajak ekonomi digital dan direncanakan selesai pada akhir tahun 2020. Namun demikian, negara-negara di dunia pun mulai menyusun langkah-langkah sepihak atau unilateral dalam pengenaan pajak ekonomi digital.

Melalui Peraturan Pengganti UndangUndang Nomor 1 Tahun 2020 yang kemudian diundangkan menjadi Undang-Undang Nomor 2 Tahun 2020 tentang Kebijakan Keuangan Negara dan Stabilitas Sistem Keuangan untuk Penanganan Pandemi COVID-19 dan/atau dalam Rangka Menghadapi Ancaman yang Membahayakan Perekonomian Nasional dan/atau Stabilitas Sistem Keuangan (Sekretariat Negara Indonesia, 2020), Indonesia membentuk payung hukum dalam bentuk undang-undang untuk mengenakan pajak pada aktivitas ekonomi digital. Hal ini sejalan dengan Peraturan Pemerintah Nomor 80 Tahun 2019 tentang Perdagangan Melalui Sistem Elektronik (PP 80/2019) yang telah dibentuk sebelumnya di mana terdapat pula pengaturan mengenai pengenaan pajak ekonomi digital (Sekretariat Negara Indonesia, 2019).

Ditengah dorongan untuk menutup defisit anggaran karena banyaknya stimulus di masa pandemi ini, Pemerintah mengeluarkan aturan turunan yakni beleid Peraturan Menteri Keuangan Nomor 48/PMK.03/2020 tentang Tata Cara Penunjukan Pemungut, Pemungutan, dan Penyetoran, serta Pelaporan Pajak Pertambahan Nilai Atas Pemanfaatan Barang Kena Pajak Tidak Berwujud dan/atau Jasa Kena Pajak dari Luar Daerah Pabean di dalam Daerah Pabean Melalui Perdagangan Melalui Sistem Elektronik (PMK 48/2020) sebagai salah satu sumber penerimaan baru (Kementerian Keuangan, 2020). Dengan kata lain, dapat diartikan bahwa Pemerintah menjadikan Pajak Pertambahan Nilai sebagai solusi atas permasalahan digitalisasi ekonomi. Namun yang menjadi pertanyaan adalah apakah langkah kebijakan yang diambil oleh Pemerintah sudah tepat, mengingat, pemberlakuan suatu regulasi tentunya memiliki dampak bagi pihak-pihak terkait (stakeholder). Studi ini menggunakan metode Regulatory Impact Assessment (RIA) atas PMK 48/2020 untuk melihat dampak pengenaan pajak pertambahan nilai yang diatur dalam regulasi tersebut.

\subsection{Rumusan Masalah}

PMK 48/2020 diharapkan dapat menjadi sebuah landasan hukum dalam pelaksanaan pengenaan pajak pertambahan nilai sebagai salah satu solusi atas permasalahan digitalisasi ekonomi. Untuk itu, penelitian ini akan menganalisis tentang bagaimana dampak dari langkah kebijakan yang diambil oleh Pemerintah dalam menerbitkan PMK 48/2020. 


\subsection{Kerangka Berpikir}

Penelitian ini secara spesifik menganalisis dampak dari langkah kebijakan yang diambil oleh Pemerintah dalam menerbitkan PMK 48/2020. Tujuan yang ingin dicapai dalam penelitian ini adalah terciptanya peraturan pengenaan PPN yang setara antara pelaku usaha Perdagangan Melalui Sistem Elektronik (PMSE) baik luar negeri dan dalam negeri dengan pelaku usaha Non PMSE (konvensional).

Saat ini pengenaan PPN dalam negeri hanya dilakukan pada perdagangan konvensional, sedangkan PMSE belum dikenakan PPN. Melalui RIA akan disusun kebijakan yang lebih efektif guna menciptakan keadilan bagi seluruh subjek pajak. Analisis yang dilakukan mempertimbangkan manfaat dan biaya dari setiap alternatif kebijakan dengan menggunakan kerangka berpikir sesuai dengan Gambar 1 dibawah ini.



Gambar 1. Kerangka Pikir Penelitian Sumber: Analisis Penulis

\section{Tinjauan Pustaka}

\subsection{Peraturan Menteri Keuangan Nomor 48/PMK.03/2020}

PMK 48/2020 telah diundangkan pada 5 Mei 2020 dan berlaku pada 1 Juli 2020. Struktur pengaturan PMK 48/2020 sebagai berikut:
Tabel 1. Struktur Pengaturan PMK 48/2020

\begin{tabular}{ll}
\hline Struktur & \multicolumn{1}{c}{ Keterangan } \\
\hline Pasal 1 & Definisi umum \\
\hline Pasal 2 & $\begin{array}{l}\text { Ketentuan pengenaan PPN } \\
\text { PMSE }\end{array}$ \\
\hline \multirow{2}{*}{ Pasal 3 } & $\begin{array}{l}\text { Ketentuan pemanfaatan BKP } \\
\text { Tidak Berwujud }\end{array}$ \\
\hline \multirow{2}{*}{ Pasal 4 } & $\begin{array}{l}\text { Kriteria pelaku usaha PMSE } \\
\text { yang ditunjuk sebagai pemungut }\end{array}$ \\
\hline Pasal 5 & $\begin{array}{l}\text { Kriteria pembeli barang } \\
\text { dan/atau penerima jasa }\end{array}$ \\
\hline Pasal 6 & $\begin{array}{l}\text { Ketentuan dasar pengenaan } \\
\text { PPN dan tarif }\end{array}$ \\
\hline Pasal 7 & Ketentuan bukti pungut PPN \\
\hline Pasal 8 & Ketentuan penyetoran PPN \\
\hline Pasal 9 & Ketentuan pelaporan PPN \\
\hline Pasal 10 & $\begin{array}{l}\text { Ketentuan laporan rincian } \\
\text { transaksi PPN }\end{array}$ \\
\hline
\end{tabular}

Pasal 11 Waktu berlakunya PMK

Sumber: Kementerian Keuangan RI (2020)

Pada intinya PMK 48/2020 mengatur mengenai PPN yang dikenakan atas pemanfaatan Barang Kena Pajak (BKP) tidak berwujud dan/atau Jasa Kena Pajak (JKP) dari luar daerah pabean di dalam daerah pabean melalui Perdagangan Melalui Sistem Elektronik (PMSE) (Kementerian Keuangan RI, 2020). PPN atas pemanfaatan BKP tidak berwujud dan/atau JKP dari luar daerah pabean tersebut dipungut, disetorkan, dan dilaporkan oleh pelaku usaha PMSE yang ditunjuk oleh Direktur Jenderal Pajak. Adapun pelaku usaha PMSE adalah orang pribadi atau badan yang melakukan kegiatan usaha di bidang PMSE. Tarif yang dikenakan yaitu $10 \%$ dari nilai berupa uang yang dibayar oleh pembeli barang dan/atau penerima jasa.

Pelaku usaha PMSE dapat berupa pedagang luar negeri, penyedia jasa luar negeri, penyelenggara PMSE (PPMSE) luar negeri, dan/atau PPMSE dalam negeri. Definsi PPMSE yaitu pelaku usaha penyedia sarana komunikasi elektronik yang digunakan untuk transaksi perdagangan. Sedangkan, 
Kementerian Keuangan RI (2020) menyebutkan bahwa pedagang/penyedia jasa luar negeri adalah orang pribadi atau badan yang bertempat tinggal atau bertempat kedudukan di luar daerah pabean yang melakukan transaksi dengan pembeli barang di dalam daerah pabean melalui sistem elektronik.

\subsection{Regulatory Impact Analysis}

\section{Regulatory Impact Assesment (RIA)} menurut OECD (2008) adalah sebuah alat mendasar untuk membantu Pemerintah dalam menilai dampak peraturan baru ataupun yang telah ada. Dalam meningkatkan efisiensi, transparansi, dan akuntabilitas peraturan dalam pengambilan keputusan, RIA telah digunakan sebagai alat utama yang telah dipraktekkan di negara-negara anggota OECD dan Uni Eropa (Kirpatrick, 2014; Adelle dan Weiland, 2012 dalam Adelle et al, 2015). Proses dalam menganalisis dan mengkomunikasikan secara sistematis terhadap kebijakan baik kebijakan baru maupun yang telah ada merupakan RIA menurut Bappenas dalam Suska (2012), sehingga Suska menyebutkan terdapat tiga buah butir penting yakni metode RIA mencakup kegiatan analisis dan pengkomunikasian, obyek metode RIA adalah kebijakan, dan metode RIA dapat diterapkan untuk kebijakan baru maupun yang telah ada.

Analisis RIA yang dilakukan menggunakan sepuluh langkah pertanyaan sesuai yang digunakan dalam pedoman OECD (2008) yakni:

1. Apakah masalahnya dengan benar telah didefinisikan?

2. Apakah tindakan pemerintah sudah tepat?

3. Apakah regulasi yang ada merupakan yang terbaik untuk langkah pemerintah?

4. Apakah ada dasar hukumnya untuk sebuah peraturan?

5. Berapa tingkatan birokrasi pemerintah yang dilibatkan untuk koordinasi regulasi ini?
6. Apakah regulasi yang ada bermanfaat, dibanding biayanya?

7. Apakah distribusi akan dampaknya transparan di masyarakat?

8. Apakah peraturan tersebut jelas, konsisten, dipahami dan diakses oleh pengguna?

9. Apakah semua pihak yang berkepentingan memiliki kesempatan yang sama untuk menyampaikan pandangan mereka?

10. Bagaimana kepatuhan akan regulasi itu dapat dicapai?

\subsection{Penelitian Terdahulu}

Penelitian terdahulu mengenai perpajakan lintas batas telah banyak dilakukan. Goolsbee, Austan. (2001) menyebutkan bahwa di negara-negara Uni Eropa mengenakan PPN untuk pembelian yang berasal dari negara lain melalui bea masuk. Untuk negara-negara berkembang akan menghadapi trade-off dari menghasilkan pendapatan dari dengan mengabaikan efisiensi ekonomi dan membangun kebijakan untuk PPN digital atau perusahaan di dunia maya (Bunn, D. et al., 2020). Terdapat tiga opsi yang direkomendasikan Task Force on The Digital Economy (TFDE) dalam mengatasi tantangan penerapan PPN digital atas barang atau jasa yang dijual oleh perusahaan luar negeri dan untuk mencegah potensi timbulnya pergeseran laba, yaitu mengubah pengecualian atas definisi permanent establishment(PE), merekomendasikan penerapan pedoman PPN internasional termasuk pengenaan PPN dalam transaksi lintas batas, dan nexus baru seperti penerapan kebijakan significanct economic presence, pemotongan pajak untuk transaksi digital tertentu, dan kebijakan equalization lery (OECD, 2015).

Prinsip-prinsip PPN terhadap transaksi digital yang berlaku Indonesia menurut Utomo (2017) dipengaruhi oleh pedoman organisasi internasional yang terdiri dari United Nations (UN) Model Double Taxation Convention between 
Developed and Developing Countries dan International VAT/GST Guidelines and Tax Convention on Income and on Capital Organisation for Economic Co-operation and Development (OECD). Selanjutnya Utomo membagi tiga metode pembayaran dalam transaksi konten digital lintas perbatasan, yaitu menggunakan kartu kredit yakni dengan melakukan penyetoran sendiri PPN oleh pelaku transaksi ke kas negara paling lambat tanggal 15 bulan berikutnya, gift cards yakni dengan pengurangan saldo atas voucher fisik yang telah diisi sebelumnya, dan penagihan operator langsung yakni dengan pemotongan pulsa oleh operator seluler atas tiap transaksi.

Penelitian pajak ekonomi digital salah satunya oleh Olbert, M. et al. (2019) menemukan bukti empiris bahwa tantangan pajak ekonomi digital masih belum tuntas. Pembuat kebijakan harus memperhatikan pengumpulan pajak konsumsi dan penegakan tujuan dengan latar belakang kesenjangan PPN yang besar diantara Uni Eropa, dengan mengusulkan konsep untuk solusi pajak yang tepat waktu berbasis konsensus bisnis dalam ekonomi digital dimasa yang akan datang.

Penelitian RIA terhadap peraturan perpajakan telah dilakukan oleh beberapa peneliti. Salah satunya menggunakan RIA untuk penilaian ex-post dari dampak ekonomi penerapan aturan perpajakan di Slovenia karena aturan pajak yang diperketat ternyata tidak menyebabkan penurunan rasio utang internal (Jovanovic, T., Klun, M., 2017). Penelitian yang mengambil studi kasus di Australia oleh Sawyer, A. (2008) juga menggunakan RIA untuk menganalisis dampak rancangan undang undang terkait pajak, diperoleh hasil bahwa RIA dan RIS (Regulatory Impact Statement) memiliki peranan penting dalam upaya mengurangi beban kepatuhan wajib pajak dan mampu meningkatkan akuntabilitas Pemerintah dalam pengenaan pajak. Australia juga telah memiliki dokumen RIS mengenai
Land Tax Regulations 2015 (State Revenue Office of Victoria, 2015) yang membahas mengenai pajak tanah di Victoria yang berlaku pada bulan Januari 2006. Setiap pemilik tanah dikenakan pajak atas nilai agregat dari semua tanah kena pajak yang dimiliki. RIS diperlukan untuk menilai dampak dari Land Tax Regulations dengan melakukan tiga buah pilihan alternatif yaitu opsi 1: tidak ada biaya aplikasi yang telah ditentukan, opsi 2: menentukan biaya terpisah antara aplikasi online dengan konvensional berdasarkan biaya dan indeks, dan opsi 3: menentukan satu biaya untuk semua aplikasi berdasarkan biaya dan indeks saat ini. Dalam dokumen RIS tersebut ditentukan pendapatan dan biaya dari masing-masing opsi atas dasar SRO menerima rata-rata 170.000 aplikasi setiap tahunnya, sehingga diperoleh hasil bahwa opsi 3 merupakan opsi yang disukai oleh State Revenue Office (State Revenue Office of Victoria, 2015).

RIA dapat digunakan untuk mengkaji dampak atas peraturan baru maupun yang telah ada. Penelitian oleh Huang, J. et al. (2013) menggunakan metode RIA untuk mengkaji dampak dari Graphic Warning Labels (GWL) terhadap tingkat merokok di Kanada, menggunakan metode penelitian kuasi eksperimen dengan model DiD (Difference in Difference) dengan menggunakan data prevelensi merokok orang dewasa dari tahun 1991-2009 (sembilan tahun sebelum dan setelah GWL diperkenalkan di Kanada) dan USA sebagai kelompok kontrol. Huang, J. et al. memperoleh hasil bahwa terjadi pengurangan signifikan secara statistik setelah penerapan GWL di Kanada dibandingkan dengan di USA, sehingga hasil penelitian ini dapat mengubah peraturan baru yang telah ada di Kanada.

\section{Metode Penelitian}

Studi ini menggunakan pendekatan kualitatif. Untuk mendukung penulisan ini, dilakukan kegiatan studi literatur yang 
mendalam. Metode penelitian kualitatif menurut Sugiyono (2014) merupakan penelitian yang dilakukan pada kondisi ilmiah, lebih bersifat deskriptif, lebih menekankan pada proses daripada produk maupun outcome, analisis data secara induktif, dan lebih menekankan makna.

Metode analisa yang digunakan mempertimbangkan check list RIA dalam panduan OECD (2008) meliputi tujuan, masalah, proposal peraturan, analisis biaya manfaat, membandingkan biaya manfaat, identifikasi alternatif, membandingkan biaya manfaat dari alternatif, membandingkan alternatif dengan proposal peraturan, dan konsultasi. Sebagai pembanding, dipertimbangkan juga proses RIA menurut Bappenas (2011) yaitu sebagai berikut:

1. Identifikasi dan analisis masalah terkait kebijakan. Pada tahap ini, sangat penting untuk membedakan antara masalah dengan gejala (symptom).

2. Penetapan tujuan. Ini penting karena untuk mengukur efektivitas adalah apakah tujuan kebijakan tersebut tercapai atau tidak.

3. Pengembangan berbagai alternatif kebijakan untuk mencapai tujuan. Opsi do nothing dibandingkan dengan opsi-opsi lain.

4. Penilaian terhadap pilihan alternatif kebijakan, baik dari sisi legalitas maupun biaya dan manfaat.

5. Pemilihan kebijakan terbaik dengan menggunakan analisis biaya-manfaat.

6. Penyusunan strategi implementasi. Ini penting untuk tidak hanya memahami tentang apa yang akan dilakukan tetapi juga bagaimana melakukannya.

7. Partisipasi masyarakat di semua proses. Komponen masyarakat yang harus didengar pendapatnya adalah mereka yang akan menerima dampak adanya kebijakan tersebut.
Analisa biaya dan manfaat dilakukan dengan pendekatan deskriptif kualitatif seperti metode yang digunakan untuk menjelaskan beberapa manfaat yang dapat diperoleh dari RIA Rancangan Undang-undang Konvergensi Teknologi Informasi dan Komunikasi, kemudian dibandingkan dengan biaya yang mungkin ada akibat peraturan tersebut (Ridwan, W., Krisnadi, I., 2011). Analisis hasil akan dilakukan dengan membandingkan manfaat dan biaya dari tiga buah alternatif kebijakan yang diskenariokan. Sesuai dengan rumusan persamaan dibawah ini:

Persamaan Analisis Biaya dan Manfaat

$$
\frac{M A l t i}{B A l t i}>\frac{M A l t j}{B A l t j}
$$

dimana:

M Alt: Total manfaat suatu skenario alternatif B Alt: Total biaya suatu skenario alternative i, j: 1, 2, 3 (menunjukkan nomor skenario alternatif

Penilaian dampak menggunakan pendekatan RIA dalam penelitian ini dibatasi pada pajak digital sesuai dengan PMK 48/2020.

\section{IV.Analisis Hasil Dan Pembahasan}

\subsection{Praktik Kebijakan di Negara Lain}

Beberapa praktik pengenaan pajak ekonomi digital secara unilateral di beberapa negara disajikan pada Tabel 2. Terdapat tiga kebijakan yang diidentifikasi telah diterapkan untuk memajaki ekonomi digital seperti diverted profit tax, equalization levy, dan digital service tax. Pada umumnya kebijakan ini bersifat unilateral dan berada di luar lingkup Perjanjian Penghindaran Pajak Berganda (P3B) sehingga dapat berpotensi terciptanya pengenaan pajak berganda atas suatu penghasilan yang dikenakan pajak di negara domisili. 
Tabel 2. Praktik Pengenaan Pajak Ekonomi Digital Di Beberapa Negara

\begin{tabular}{|c|c|c|c|c|c|}
\hline No & Negara & Kebijakan & Subjek & Objek & Tarif \\
\hline 1 & $\begin{array}{l}\text { Inggris, } \\
\text { Australia, dan } \\
\text { New Zealand } \\
(\mathrm{NZ})\end{array}$ & Diverted Profit Tax & Perusahaan & $\begin{array}{l}\text { Seluruh penyerahan } \\
\text { barang dan/atau } \\
\text { jasa yang dilakukan } \\
\text { perusahaan }\end{array}$ & $\begin{array}{l}\text { Inggris (25\%), } \\
\text { Australia dan NZ (40\%) } \\
\text { atas laba yang dialihkan } \\
\text { dengan ambang batas } \\
\text { penjualan 10 juta Euro }\end{array}$ \\
\hline 2 & India & Equalization Levy & $\begin{array}{l}\text { Individu } r \text { atau } \\
\text { Perusahaan (dalam } \\
\text { negeri dan luar } \\
\text { negeri) }\end{array}$ & Jasa digital & $\begin{array}{l}6 \% \text { dari penjualan } \\
\text { dengan ambang batas } \\
\text { penjualan } 1.500 \text { USD }\end{array}$ \\
\hline 3 & Uni Eropa & Digital Service Tax & Perusahaan & Jasa digital & $\begin{array}{l}3 \% \text { dari penghasilan } \\
\text { bruto dengan ambang } \\
\text { batas pendapatan } 50 \\
\text { juta Euro di Uni Eropa } \\
\text { dan } 750 \text { juta Euro di } \\
\text { dunia }\end{array}$ \\
\hline
\end{tabular}

Sumber: Basak, Sayan. (2016), Santos, Ramon Tomazela. (2016), diolah Penulis.

Berdasarkan tabel diatas, kebijakankebijakan mengenai pengenaan pajak ekonomi digital di negara lain hampir seragam yaitu untuk menciptakan level of playing field (perlakuan yang setara) antar pelaku usaha. Lebih lanjut, kebijakan equalization lery cukup sesuai untuk diterapkan di Indonesia. Hal utama yang menjadi pertimbangan adalah kepastian hukum dari kebijakan equalization levy. Ruang lingkup produk atau barang dan/atau jasa yang tercakup dalam equalization lery juga dapat diperluas sesuai dengan pertimbangan kondisi di Indonesia. Ruang lingkup pelaku bisnis yang dikenakan equalization lery juga lebih luas karena mencakup perseorangan dan badan serta ambang batas penghasilan yang lebih rendah dengan menggunakan nilai penghasilan bruto. Indonesia dapat mengadopsi kebijakan pajak ekonomi digital dari beberapa negara lain dengan tetap mempertimbangkan kondisi dan situasi di Indonesia serta kepentingan domestik.

\subsection{RIA Peraturan Menteri Keuangan Nomor 48/PMK.03/2020}

Analisis RIA dilakukan dengan menggabungkan langkah-langkah dalam check list RIA OECD dan tahapan proses RIA Bappenas. Langkah-langkah ini termasuk menjawab sepuluh pertanyaan dasar RIA dan melakukan analisis RIA sesuai dengan tahapan yang telah ditetapkan.

\subsubsection{Sepuluh Pertanyaan RIA}

Sepuluh pertanyaan dalam RIA merupakan standar yang ditetapkan oleh OECD dalam merumuskan peraturan sehingga tercipta peraturan yang lebih baik. Pertanyaan ini bertujuan untuk meningkatkan kualitas peraturan yang mampu mengakomodasi semua pemangku kepentingan. Sepuluh pertanyaan dan jawaban disajikan pada Tabel 3.

\subsubsection{Tahapan Analisis RIA}

Tahapan analisis RIA merujuk panduan OECD dan Bappenas sebagai berikut:

1) Perumusan Masalah

Berdasarkan latar belakang yang telah disampaikan di bagian pendahuluan, maka permasalahan utama yang dihadapi adalah belum dikenakannya pajak ekonomi digital di Indonesia, dan solusi yang diambil Pemerintah dengan mengenakan PPN atas pemanfaatan BKP tidak berwujud dan/atau JKP dari luar daerah pabean di dalam daerah pabean melalui PMSE. 
Tabel 3 Jawaban Sepuluh Pertanyaan RIA

\begin{tabular}{|c|c|c|}
\hline No & Pertanyaan & Jawaban \\
\hline 1 & $\begin{array}{l}\text { Apakah masalahnya dengan } \\
\text { benar telah didefinisikan? }\end{array}$ & $\begin{array}{l}\text { Sesuai dengan isi PMK 48/2020, identifikasi masalah } \\
\text { sudah didefinisikan dengan benar. }\end{array}$ \\
\hline 2 & $\begin{array}{l}\text { Apakah tindakan pemerintah } \\
\text { sudah tepat? }\end{array}$ & $\begin{array}{l}\text { Tindakan pemerintah sudah tepat, menetapkan PMK } \\
48 / 2020 \text { dalam rangka melindungi basis pajak } \\
\text { Indonesia dan melindungi pelaku usaha PMSE dalam } \\
\text { negeri. }\end{array}$ \\
\hline 3 & $\begin{array}{l}\text { Apakah regulasi yang ada } \\
\text { merupakan yang terbaik untuk } \\
\text { langkah pemerintah? }\end{array}$ & $\begin{array}{l}\text { PMK 48/2018 mampu melindungi pelaku usaha } \\
\text { PMSE dalam negeri dan menjaga basis pajak } \\
\text { Indonesia, namun belum mampu menciptakan level of } \\
\text { playing field (perlakuan yang setara) antar pelaku } \\
\text { usaha PMSE dan non PMSE. }\end{array}$ \\
\hline 4 & $\begin{array}{l}\text { Apakah ada dasar hukumnya } \\
\text { untuk sebuah peraturan? }\end{array}$ & $\begin{array}{l}\text { Ada, sesuai dengan klausa Menimbang dan } \\
\text { Mengingat dalam PMK 48/2020 }\end{array}$ \\
\hline 5 & $\begin{array}{l}\text { Berapa tingkatan birokrasi } \\
\text { pemerintah yang dilibatkan } \\
\text { untuk koordinasi regulasi ini? }\end{array}$ & $\begin{array}{l}\text { Birokrasi yang dilibatkan antara lain Kementerian } \\
\text { Keuangan (Direktorat Jenderal Pajak, Direktorat } \\
\text { Jenderal Bea dan Cukai), Kementerian Perdagangan, } \\
\text { Kementerian Komunikasi dan Informatika, dan Bank } \\
\text { Indonesia. }\end{array}$ \\
\hline 6 & $\begin{array}{l}\text { Apakah regulasi yang ada } \\
\text { bermanfaat, dibanding biayanya } \\
?\end{array}$ & $\begin{array}{l}\text { Bermanfaat, baik dalam jangka pendek maupun } \\
\text { jangka panjang. Namun, manfaat yang diperoleh } \\
\text { dengan peraturan saat ini masih dapat ditingkatkan. }\end{array}$ \\
\hline 7 & $\begin{array}{l}\text { Apakah distribusi akan } \\
\text { dampaknya transparan di } \\
\text { masyarakat? }\end{array}$ & $\begin{array}{l}\text { Transparan dan perlu pengawasan, monitoring, dan } \\
\text { evaluasi dari seluruh pemangku kepentingan. }\end{array}$ \\
\hline 8 & $\begin{array}{l}\text { Apakah peraturan tersebut jelas, } \\
\text { konsisten, dipahami dan diakses } \\
\text { oleh pengguna? }\end{array}$ & $\begin{array}{l}\text { Jelas, konsisten dan dapat diakses oleh seluruh rakyat } \\
\text { Indonesia. }\end{array}$ \\
\hline 9 & $\begin{array}{l}\text { Apakah semua pihak yang } \\
\text { berkepentingan memiliki } \\
\text { kesempatan yang sama untuk } \\
\text { menyampaikan pandangan } \\
\text { mereka? }\end{array}$ & $\begin{array}{l}\text { Semua pihak yang berkepentingan memiliki } \\
\text { kesempatan yang sama untuk menyampaikan } \\
\text { pendapatnya. Bahkan memiliki kesempatan untuk } \\
\text { menggugat peraturan ini ke Mahkamah Konstitusi. }\end{array}$ \\
\hline 10 & $\begin{array}{l}\text { Bagaimana kepatuhan akan } \\
\text { regulasi itu dapat dicapai? }\end{array}$ & $\begin{array}{l}\text { Diperlukan administrasi dan teknologi perpajakan } \\
\text { yang memadai, pengawasan dari otoritas pajak, kerja } \\
\text { sama dengan pelaku usaha PMSE baik luar negeri } \\
\text { dan dalam negeri, serta harus dilakukan monitoring } \\
\text { dan evaluasi yang berkelanjutan. }\end{array}$ \\
\hline
\end{tabular}

Sumber: diolah Penulis

2) Identifikasi Tujuan

Pengenaan pajak ekonomi digital bertujuan untuk untuk menciptakan level of playing field (perlakuan yang setara) antar pelaku usaha, melindungi pengusaha domestik, dan menjaga basis pajak Indonesia. 
3) Identifikasi Alternatif Kebijakan

- Alternatif 1: Do Nothing Opsi do nothing diartikan bahwa Pemerintah tidak mengenakan PPN atas PMSE.

- Alternatif 2: Pengenaan PPN sesuai PMK 48/2020

Mengenakan PPN 10\% atas pemanfaatan BKP tidak berwujud dan/atau JKP dari luar daerah pabean di dalam daerah pabean melalui PMSE.

- Alternatif 3: Pengenaan PPN dengan penambahan ketentuan baru

Berdasarkan analisis perbandingan kebijakan di beberapa negara dan sesuai dengan Ottawa Framework Recommendation (OECD, 2003) bahwa desain kebijakan pajak ekonomi digital harus mempertimbangkan netralitas dan keadilan bagi pelaku usaha PMSE dan pelaku usaha konvensional, sehingga perlu penambahan ketentuan baru sebagai berikut:

(a) Menambahkan lingkup pelaku usaha PMSE, yaitu pedagang dalam negeri dan penyedia jasa dalam negeri, baik perseorangan atau badan.

(b) Menambahkan objek pajak PMSE, yaitu barang kena pajak (BKP) berwujud.

4) Analisis Biaya dan Manfaat

Analis biaya dan manfaat yang digunakan merupakan pengukuran secara kualitatif, dengan menggunakan asumsi nilai bahwa jika terdapat suatu manfaat maka dinilai menjadi suatu hal yang positif, sedangkan jika terdapat biaya dinilai menjadi suatu hal yang negatif. Dalam menentukan manfaat dan biaya dari masingmasing alternatif dilakukan telaah literatur mengenai pajak ekonomi digital, seperti hukum pajak domestik, penerapan di beberapa negara, dan rekomendasi best practice internasional.

- Alternatif 1: Do Nothing

Tabel 4 menunjukkan hasil analisis biaya dan manfaat jika Pemerintah tidak mengenakan PPN atas PMSE.

Berdasarkan analisis manfaat dan biaya, jika pemerintah tidak mengenakan PPN atas PMSE maka terdapat lebih banyak biaya yang ditimbulkan yang akan ditanggung oleh Pemerintah dan pelaku usaha non PMSE. Kerugian yang paling signifikan adalah basis pajak PMSE tidak dapat dioptimalkan oleh Pemerintah, dan tidak terciptanya perlakuan yang setara antara pelaku usaha PMSE dan pelaku usaha non PMSE.

- Alternatif 2: Pengenaan PPN sesuai PMK 48/2020

Dengan opsi ini yang ditunjukkan pada tabel 5, Pemerintah hanya mengenakan PPN barang tak berwujud atau jasa digital dari pelaku usaha PMSE luar negeri.

Berdasarkan analisis manfaat dan biaya pada tabel 5, jika pemerintah mengenakan PPN barang tak berwujud/jasa digital dari pelaku usaha PMSE luar negeri maka akan timbul biaya pada pelaku usaha PMSE luar negeri. Kerugian ini dikarenakan tidak terciptanya perlakuan yang setara antara pelaku usaha PMSE luar negeri dan pelaku usaha PMSE dalam negeri. Di sisi Pemerintah, poin utamanya adalah akan muncul manfaat di mana terdapat potensi penerimaan pajak dari PMSE barang atau jasa digital lintas batas (luar negeri) mencapai Rp.10,4 triliun (Santoso, 2020). 
Tabel 4. Analisis Biaya dan Manfaat Alternatif 1

\begin{tabular}{|c|c|c|}
\hline $\begin{array}{c}\text { Pemangku } \\
\text { Kepentingan }\end{array}$ & Manfaat (Positif) & Biaya (Negatif) \\
\hline $\begin{array}{l}\text { Pemerintah } \\
\text { Pusat }\end{array}$ & & $\begin{array}{l}\text { Tidak ada penerimaan pajak dari PMSE } \\
\text { Tidak tercipta perlakuan yang setara antara } \\
\text { pelaku usaha non PMSE dan pelaku usaha } \\
\text { PMSE dalam negeri } \\
\text { Tidak tercipta perlakuan yang setara antara } \\
\text { pelaku usaha non PMSE dan pelaku usaha } \\
\text { PMSE luar negeri } \\
\text { Keluhan dari pelaku usaha non PMSE karena } \\
\text { tidak mendapatkan perlakuan pajak yang } \\
\text { sama } \\
\text { Basis pajak PMSE dalam negeri tidak dapat } \\
\text { dioptimalkan } \\
\text { Basis pajak PMSE oleh pelaku usaha luar } \\
\text { negeri tergerus atau dinikmati oleh negara } \\
\text { lain } \\
\text { Pasar dalam negeri dipenuhi oleh barang } \\
\text { atau jasa dari pelaku usaha PMSE luar negeri }\end{array}$ \\
\hline Masyarakat & $\begin{array}{l}\text { Harga barang atau jasa yang } \\
\text { dijual melalui PMSE lebih } \\
\text { rendah }\end{array}$ & \\
\hline $\begin{array}{lr}\text { Pelaku } & \text { usaha } \\
\text { PMSE } & \text { luar } \\
\text { negeri } & \end{array}$ & $\begin{array}{l}\text { Dapat memaksimumkan } \\
\text { keuntungan karena tidak } \\
\text { dikenakan PPN } \\
\text { Konsumen bertambah karena } \\
\text { harga yang ditawarkan lebih } \\
\text { rendah }\end{array}$ & \\
\hline $\begin{array}{ll}\text { Pelaku } & \text { usaha } \\
\text { PMSE } & \text { dalam } \\
\text { negeri } & \end{array}$ & $\begin{array}{l}\text { Dapat memaksimumkan } \\
\text { keuntungan karena tidak } \\
\text { dikenakan PPN } \\
\text { Konsumen bertambah karena } \\
\text { harga yang ditawarkan lebih } \\
\text { rendah }\end{array}$ & \\
\hline $\begin{array}{lr}\text { Pelaku } & \text { usaha } \\
\text { Non } & \text { PMSE } \\
\text { dalam negeri }\end{array}$ & & $\begin{array}{l}\text { Konsumen berkurang karena harga yang } \\
\text { ditawarkan lebih tinggi } \\
\text { Tidak dapat memaksimumkan keuntungan } \\
\text { karena dikenakan PPN } \\
\text { Kecemburuan sosial kepada pelaku usaha } \\
\text { PMSE }\end{array}$ \\
\hline Total & $(+5)$ & $(-10)$ \\
\hline
\end{tabular}

Sumber: Analisis Penulis 
Tabel 5. Analisis Biaya dan Manfaat Alternatif 2

\begin{tabular}{|c|c|c|}
\hline $\begin{array}{c}\text { Pemangku } \\
\text { Kepentingan }\end{array}$ & Manfaat (Positif) & Biaya (Negatif) \\
\hline $\begin{array}{l}\text { Pemerintah } \\
\text { Pusat }\end{array}$ & $\begin{array}{l}\text { 1. Ada penerimaan pajak } \\
\text { dari PMSE barang atau } \\
\text { jasa digital lintas batas } \\
\text { (luar negeri) mencapai } \\
\text { Rp.10,4 triliun } \\
\text { 2. Basis pajak PMSE barang } \\
\text { atau jasa digital oleh } \\
\text { pelaku usaha luar negeri } \\
\text { tidak tergerus atau } \\
\text { dinikmati negara lain } \\
\text { 3. Penerapannya mudah } \\
\text { karena sistem yang tidak } \\
\text { terlalu berbeda dengan } \\
\text { sistem yang berlaku saat } \\
\text { ini }\end{array}$ & $\begin{array}{l}\text { 1. Biaya administrasi perpajakan } \\
\text { untuk otoritas pajak } \\
\text { 2. Basis pajak PMSE dalam negeri } \\
\text { belum dapat dioptimalkan } \\
\text { 3. Tidak tercipta perlakuan yang } \\
\text { setara antara pelaku usaha } \\
\text { PMSE luar negeri dan PMSE } \\
\text { dalam negeri } \\
\text { 4. Tidak tercipta perlakuan yang } \\
\text { setara antara pelaku usaha } \\
\text { PMSE dan pelaku usaha non } \\
\text { PMSE pelaku usaha } \\
\text { 5. Keluhan dari pelan } \\
\text { PMSE luar negeri karena tidak } \\
\text { mendapat perlakuan pajak yang } \\
\text { setara. }\end{array}$ \\
\hline Masyarakat & & $\begin{array}{l}\text { 1. Harga barang tak berwujud atau } \\
\text { jasa digital yang dijual melalui } \\
\text { PMSE lintas batas lebih tinggi }\end{array}$ \\
\hline $\begin{array}{lr}\text { Pelaku } & \text { usaha } \\
\text { PMSE luar } \\
\text { negeri }\end{array}$ & & $\begin{array}{l}\text { 1. Tidak dapat memaksimumkan } \\
\text { keuntungan karena dikenakan } \\
\text { PPN } \\
\text { 2. Konsumen berkurang karena } \\
\text { harga yang ditawarkan lebih } \\
\text { tinggi. }\end{array}$ \\
\hline
\end{tabular}

Pelaku usaha 1. Dapat memaksimumkan

PMSE dalam keuntungan karena tidak negeri dikenakan PPN

2. Konsumen bertambah karena harga yang ditawarkan lebih rendah.

3. Terlindungi dari serbuan barang atau jasa digital pelaku usaha PMSE luar negeri

Pelaku usaha

Non PMSE

dalam negeri
1. Konsumen berkurang karena harga yang ditawarkan lebih tinggi.

2. Tidak dapat memaksimumkan keuntungan karena dikenakan PPN

\section{Total}

Sumber: Analisis Penulis 
- Alternatif 3: Pengenaan PPN dengan penambahan ketentuan baru

Dengan opsi ini, Pemerintah akan memberikan perlakuan yang setara antar pelaku usaha (pelaku usaha PMSE luar negeri dengan pelaku usaha PMSE dalam negeri, dan pelaku usaha PMSE dengan pelaku usaha konvensional). Hal ini sesuai dengan penjelasan Pasal 16B Undang-Undang PPN yang mengamanatkan diberlakukan dan diterapkannya perlakuan yang sama terhadap semua Wajib Pajak atau terhadap kasus-kasus dalam bidang perpajakan yang pada hakikatnya sama dengan berpegang teguh pada ketentuan peraturan perundang-undangan (Sekretariat Negara Indonesia, 2009). Selain itu, opsi ini juga mengadopsi Ottawa Framework Recommendation (OECD, 2003) di mana desain kebijakan pajak ekonomi digital harus mempertimbangkan netralitas dan keadilan bagi pelaku usaha PMSE dan pelaku usaha non PMSE (konvensional).

Berdasarkan analisis manfaat dan biaya yang ditunjukkan pada tabel 6, jika Pemerintah menerapkan alternatif 3 maka akan timbul biaya pada pelaku usaha PMSE dalam negeri. Kerugian ini dikarenakan karena barang yang selama ini tidak dikenakan PPN dalam PMSE menjadi dikenakan PPN. Namun dibanding jumlah biaya, akan muncul lebih banyak manfaat yang tercipta dalam penerapan alternatif 3. Di sisi Pemerintah, poin utamanya adalah akan muncul manfaat di mana terdapat potensi penerimaan pajak dari basis pajak PMSE dalam negeri sebesar Rp.1700 triliun (Yudhistira, 2016) dan di sisi pelaku usaha non PMSE akan mendapatkan perlakuan perpajakan yang setara dengan pelaku usaha PMSE.

Tabel 6. Analisis Biaya dan Manfaat Alternatif 3

\begin{tabular}{|c|c|c|}
\hline $\begin{array}{c}\text { Pemangku } \\
\text { Kepentingan }\end{array}$ & Manfaat (Positif) & Biaya (Negatif) \\
\hline $\begin{array}{l}\text { Pemerintah } \\
\text { Pusat }\end{array}$ & $\begin{array}{l}\text { Ada penerimaan pajak dari PMSE barang atau } \\
\text { jasa digital lintas batas (luar negeri) } \\
\text { Basis pajak PMSE barang atau jasa digital oleh } \\
\text { pelaku usaha luar negeri tidak tergerus atau } \\
\text { dinikmati negara lain } \\
\text { Basis pajak PMSE dalam negeri dapat } \\
\text { dioptimalkan sebesar Rp.1700 triliun } \\
\text { Penerapannya mudah } \\
\text { Tercipta perlakuan yang setara antara pelaku } \\
\text { usaha PMSE luar negeri dan PMSE dalam } \\
\text { negeri } \\
\text { Tercipta perlakuan yang setara antara pelaku } \\
\text { usaha PMSE dan pelaku usaha non PMSE } \\
\text { (konvensional) }\end{array}$ & $\begin{array}{l}\text { Biaya administrasi } \\
\text { perpajakan untuk otoritas } \\
\text { pajak lebih besar } \\
\text { Keluhan dari pelaku usaha } \\
\text { PMSE atas beban pajak }\end{array}$ \\
\hline Masyarakat & $\begin{array}{l}\text { Potensi pelayanan publik lebih baik dengan } \\
\text { distribusi penerimaan pajak }\end{array}$ & $\begin{array}{l}\text { Harga barang berwujud } \\
\text { dan tak berwujud atau } \\
\text { jasa digital yang dijual }\end{array}$ \\
\hline
\end{tabular}




\begin{tabular}{|c|c|c|}
\hline & & $\begin{array}{lll}\text { melalui } & \text { PMSE } & \text { lebih } \\
\text { tinggi. } & & \\
\end{array}$ \\
\hline $\begin{array}{l}\text { Pelaku usaha } \\
\text { PMSE luar } \\
\text { negeri }\end{array}$ & $\begin{array}{l}\text { Mendapatkan perlakuan setara dengan pelaku } \\
\text { usaha PMSE dalam negeri }\end{array}$ & $\begin{array}{lr}\text { Tidak } & \text { dapat } \\
\text { memaksimumkan } & \\
\text { keuntungan } & \text { karena } \\
\text { dikenakan PPN } & \\
\end{array}$ \\
\hline $\begin{array}{ll}\text { Pelaku } & \text { usaha } \\
\text { PMSE } & \text { dalam } \\
\text { negeri } & \end{array}$ & & $\begin{array}{l}\text { Tidak } \\
\text { memaksimumkan } \\
\text { keuntungan karena } \\
\text { dikenakan PPN } \\
\text { Potensi konsumen } \\
\text { berkurang karena harga } \\
\text { yang ditawarkan sama } \\
\text { dengan pedagang } \\
\text { konvensional }\end{array}$ \\
\hline
\end{tabular}

Pelaku usaha Konsumen bertambah karena harga yang

Non PMSE ditawarkan sama (bersaing)

dalam negeri Mendapatkan perlakuan setara dengan pelaku usaha PMSE

\section{Total (+10)}

Sumber: Analisis Penulis

5) Pemilihan Alternatif

Pemilihan alternatif terbaik dilakukan dengan menghitung total manfaat dan biaya yang ditimbulkan dari setiap alternatif sebagaimana ditunjukkan pada tabel 7 .

Perbandingan jumlah manfaat dan biaya alternatif 1 sebesar 0,5; alternatif 2 sebesar 0,6 dan alternatif 3 sebesar 1,4. Dengan demikian alternatif 3 adalah alternatif yang terbaik karena lebih memberikan manfaat lebih besar daripada biaya yang ditimbulkan.

Manfaat terbesar dirasakan oleh Pemerintah, sehingga manfaat tersebut dapat didistribusikan kepada masyarakat atau pelaku usaha di dalam negeri melalui pemberian subsidi atau insentif. Biaya terbesar dirasakan bagi pelaku usaha PMSE dalam negeri, hal ini dikarenakan terciptanya perlakuan yang setara dengan pedagang konvensional.

6) Konsultasi Publik

Dalam penyusunan draf RIA diperlukan konsultasi publik dengan seluruh pemangku kepentingan, seperti Pemerintah Pusat (Kementerian Keuangan, Bank Indonesia, Kementerian Komunikasi dan Informasi), pelaku usaha PMSE, pelaku usaha konvensional, dan wakil masyarakat sebagai konsumen. Konsultasi publik dapat dilakukan dengan rapat bersama ataupun focus group discussion dengan membahas aspek administratif ataupun aspek substansi peraturan. 
Tabel 7. Ringkasan Analisis Biaya dan Manfaat

\begin{tabular}{l|c|c|c|c}
\hline & $\begin{array}{c}\text { Total } \\
\text { Manfaat }\end{array}$ & $\begin{array}{c}\text { Total } \\
\text { Biaya }\end{array}$ & $\begin{array}{c}\text { Perbandingan } \\
\text { Manfaat dan Biaya }\end{array}$ & $\begin{array}{c}\text { Potensi Pajak } \\
\text { Digital }\end{array}$ \\
\hline Alternatif 1 & 5 & 10 & 0,5 & - \\
\hline Alternatif 2 & 6 & 10 & 0,6 & $\begin{array}{l}\text { Potensi } \\
\text { penerimaan } \\
\text { pajak sebesar } \\
\text { Rp.10,4 triliun }\end{array}$ \\
\hline Alternatif 3 & 10 & 7 & 1,4 & $\begin{array}{l}\text { Potensi } \\
\text { penerimaan } \\
\text { pajak PMSE } \\
\text { lintas batas } \\
\text { sebesar Rp.10,4 } \\
\text { triliun dan basis } \\
\text { pajak PMSE } \\
\text { dalam negeri } \\
\text { sebesar Rp.1700 } \\
\text { triliun }\end{array}$ \\
\hline \hline
\end{tabular}

7) Strategi Implementasi

a. Sosialisasi

Setelah PMK baru ditetapkan, perlu dilakukan sosialisasi mengenai substansi dan administrasi pengenaan pajak atas PMSE kepada seluruh pemangku kepentingan.

b. Pelaksanaan, Monitoring, dan Evaluasi

- Setelah PMK baru ditetapkan, diperlukan pengaturan yang lebih rinci dalam bentuk peraturan Direktur Jenderal Pajak mengenai tata cara pemungutan, penyetoran, dan pelaporan PPN.

- Pemerintah perlu bekerja sama secara intensif dengan penyelenggara PMSE luar negeri dan dalam negeri guna efektifnya pemberlakuan peraturan. Kerja sama ini dapat dilakukan baik dengan skema bilateral antar Pemerintah ataupun antara Pemerintah dengan penyelenggara PMSE.
- Monitoring dan evaluasi perlu terus dilakukan untuk meningkatkan kepatuhan pajak. Monitoring dapat dilakukan dengan membentuk National Payment Gateway sehingga mempermudah dalam mendapatkan data pembayaran ke luar negeri.

c. Sanksi

Diperlukan sanksi bagi pelaku usaha PMSE baik individu dan badan yang tidak memungut, menyetor, dan melapor PPN PMSE. Sanksi yang diterapkan dapat berupa denda ataupun sanksi pidana sesuai dengan perundangundangan.

\section{Kesimpulan Dan Saran}

\subsection{Kesimpulan}

Berdasarkan hasil analisis biaya dan manfaat sebagai diringkas dalam Tabel 7, alternatif 2 yaitu pengenaan PPN barang tak berwujud dan jasa digital dari pelaku usaha 
PMSE luar negeri mempunyai lebih banyak manfaat daripada alternatif 1: do nothing. Akan tetapi, alternatif 3 patut dipertimbangkan untuk diterapkan oleh Pemerintah. Alternatif 3 tersebut yakni pengenaan PPN dengan penambahan ketentuan baru seperti: (a) menambahkan lingkup pelaku usaha PMSE, yaitu pedagang dalam negeri dan penyedia jasa dalam negeri, baik perorangan atau badan; dan (b) menambahkan objek pajak PMSE, yaitu barang kena pajak (BKP) berwujud. Alternatif 3 dengan penambahan ketentuan sesuai yang dijabarkan diatas, merupakan opsi yang memberikan manfaat paling besar dan biaya paling kecil dibandingkan dengan alternatif 1 maupun alternatif 2. Penerapan alternatif 3 akan dapat menjawab seluruh tujuan pengenaan pajak ekonomi digital yaitu terciptanya perlakuan yang setara antar pelaku usaha (pelaku usaha PMSE luar negeri dengan pelaku usaha PMSE dalam negeri, dan pelaku usaha PMSE dengan pelaku usaha konvensional), perlindungan untuk pengusaha domestik dengan memberikan perlakuan yang setara, dan terjaganya basis pajak domestik.

\subsection{Saran}

Hasil penelitian merekomendasikan alternatif 3, dapat ditambahkan beberapa rekomendasi lanjutan. Selain perlu menjaga kerja sama dengan penyelenggara PMSE luar negeri dan dalam negeri, Indonesia juga perlu berkoordinasi dengan negara lain, baik di kawasan regional maupun global dalam menyusun kebijakan pajak digital. Dengan adanya koodinasi antar negara atau yurisdiksi, kebijakan pajak digital yang dibuat menjadi netral dan dapat mencegah terjadinya double taxation ataupun double non-taxation.

Dalam penelitian selanjutnya mengenai RIA terhadap pajak digital, diharapkan dapat dilakukan konsultasi publik lebih mendalam sehingga hasil penelitian akan lebih menyeluruh dengan mempertimbangkan masukkan dari seluruh pemangku kepentingan. Disamping itu, perlu pula melakukan analisis biaya manfaat secara kuantitatif agar terlihat lebih terukur secara satuan moneter.

\section{Daftar Pustaka}

Adelle, C.et al. (2015). Regulatory Impact Assessment: A Survey of Selected Developing and Emerging Economies. Linking Impact Assessment Instruments to Sustainability Expertise.

Basak, Sayan. (2016). EQL : a new perspective of e commerce taxation. Intertax Volume 44 Issue II. Kluwer Law International: 845.

Biro Hukum Bappenas. (2011). Kajian Ringkas Pengembangan Dan Implementasi Metode Regulatory Impact Analysis (RIA) Untuk Menilai Kebijakan (Peraturan Dan Non Peraturan) di Kementerian PPN/Bappenas. Jakarta: Bappenas.

Bunn, D. et al. (2020). Digital Taxation Around The World. Center for Global Tax Policy. Tax Foundation.

Goolsbee, Austan. (2001). The Implications of Electronic Commerce for Fiscal Policy (and Vice Versa). Journal of Economic Perspectives, 15 (1): 13-23.

Huang, J. et al. (2013). Cigarrete Graphic Warning Labels and Smoking Prevalence in Canada: A Critical Examination and Reformulation of The FDA Regulatory Impact Analysis.

Indonesia. (2019). Peraturan Pemerintah Nomor 80 Tahun 2019 tentang Perdagangan Melalui Sistem Elektronik. Sekretariat Negara. Jakarta.

Indonesia. (2020). Undang-Undang Nomor 2 Tahun 2020 tentang Kebijakan Keuangan Negara dan Stabilitas Sistem Keuangan 
Untuk Penanganan Pandemi COVID-19 dan/atau Dalam Rangka Menghadapi Ancaman yang Membahayakan Perekonomial Nasional dan/atau Stabilitas Sistem Keuangan. Sekretariat Negara. Jakarta.

Indonesia. (2009). Undang-Undang Nomor 8 Tahun 1983 tentang Pajak Pertambahan Nilai Barang dan Jasa dan Pajak Penjualan Atas Barang Mewah sebagaimana telah beberapa kali diubah terakhir dengan Undang-Undang Nomor 42 Tahun 2009 tentang Perubahan Ketiga atas UndangUndang Nomor 8 Tahun 1983 tentang Pajak Pertambahan Nilai Barang dan Jasa dan Pajak Penjualan Atas Barang Mewah. Sekretariat Negara. Jakarta.

Jovanovic, T., Klun, M. (2017). Tax Policies Assessment in Slovenia - Case of Interest Tax Shield. DANUBE: Law and Economics Review, 8(1), 1-17.

Kementerian Keuangan Republik Indonesia. (2020). Peraturan Menteri Keuangan Nomor 48/PMK.03/2020 Tentang Tata Cara Penunjukan Pemungut, Pemungutan, Dan Penyetoran, Serta Pelaporan Pajak Pertambahan Nilai Atas Pemanfaatan Barang Kena Pajak Tidak Berwujud Dan/Atau Jasa Kena Pajak Dari Luar Daerah Pabean Di Dalam Daerah Pabean Melalui Perdagangan Melalui Sistem Elektronik. Kementerian Hukum dan HAM. Jakarta.

Kemp, S. (2020). Digital 2020: Indonesia. Retrieved Juny 6, 2020, from https://datareportal.com/reports/digita 1-2020-indonesia

OECD. (2015). Addressing the Tax Challenges of the Digital Economy, Action 1 - 2015 Final Report, OECD/G20 Base Erosion and Profit Shifting Project, OECD Publishing, Paris.
OECD. (2003). Implementation Of The Ottawa Taxation Framework Conditions.

OECD. (2008). Introductory Handbook for Undertaking Regulatory Impact Analysis (RIA). October, 33(October), 1-27.

Olbert, M. et al. (2019). Taxation in the Digital Economy Recent Policy Developments and the Question of Value Creation. ZEW Discussion Papers, No.19-010. Leibnez Centre for European Economic Research. Ridwan, W., Krisnadi, I. (2011). Regulatory Impact Analysis Terhadap Rancangan Undang-undang Konvergensi Teknologi Informasi dan Komunikasi. InComTech, Jurnal Telekomunikasi dan Komputer, vol.2, no.2.

Santos, Ramon Tomazela. (2016). The United Kingdom's Diverted Profit Tax and Tax Treaties: An Evaluation. Bulletin for International Taxation. IBFD: 399.

Santoso, Yusuf Iman. (2020). Potensi Penerimaan Pajak Digital Bisa Sampai Rp.10,4 Triliun. Retrieved Juny 9, 2020, from https://money.kompas.com/read/2020/ 04/03/05 1200826/potensi-penerimaanpajak-digital-bisa-sampai-rp-10-4triliun?page $=$ all

Sawyer, A. (2008). Regulatory Impact Statements and Accountability: Recent Australasian Experience. Journal of Australian Taxation

State Revenue Office of Victoria. (2015). Regulatory Impact Statement- Land Tax Regulations 2015. Australia.

Statista. (2019). E-commerce in Indonesia.

Sugiyono. (2014). Metode Penelitian Kombinasi (Mixed Methods). Penerbit Alfabeta. Bandung.

Suska. (2012). Prinsip Regulatory Impact Assessment dalam Proses Penyusunan Peraturan Perundang-undangan Sesuai UU 
Nomor 12 Tahun 2011. Badan Kebijakan Fiskal, Kementerian Keuangan. Jakarta.

Utomo, R (2017). Tantangan Pengawasan PPN atas Transaksi Konten Digital. Jurnal Pajak Indonesia. Vol.1, No.1, hal.38-43.

Yudhistira, Aria W. (2016). Potensi Ekonomi

Digital Indonesia. Retrieved Juny 9, 2020, from

https://katadata.co.id/ariayudhistira/inf ografik/5e9a56bc25aa1/potensi-

ekonomi-digital-indonesia 